\title{
The Kaolin Residue and Its Use for Production of Mullite Bodies
}

\author{
M.I. Brasileiro' ${ }^{1}$, A.W.B. Rodrigues ${ }^{1}$, R.R. Menezes ${ }^{2}$, \\ G.A. Neves ${ }^{3}$ and L.N.L. Santana ${ }^{3}$ \\ ${ }^{1}$ Federal University of Ceará, Campus Cariri, Cidade Universitária, Juazeiro do Norte \\ ${ }^{2}$ Federal University of Paraíba, UFPB/PB, Cidade Universitária, João Pessoa \\ ${ }^{3}$ Federal University of Campina Grande, Campina Grande, \\ Brazil
}

\section{Introduction}

The continuous demand for higher productivity indices in the global competitive world has led to a fast decrease of the available natural resources and, at the same time, to the generation of a high volume of rejects or sub-products, most of them not directly recyclable.

The final report of the First National Conference on the Environment, 2003, emphasized the need for development of policies for environmental control and of restoration of the physical and biotic of the areas impacted by mining activities, encouraging the reuse, recycling and waste recovery and waste from mining (Neves et al., 2010).

Mineral extraction itself is a good example of reject production. Therefore, alternatives for recycling and/or reuse should be investigated and, where possible put into practice, since the waste is turned into serious problems with urban managing a complex and costly, considering the volume and mass uptake.

Mineral extraction and processing of kaolin is an example of generating a large volume of waste, such as kaolin ore and "industrial mineral" has many uses because of their color, low grain, low abrasiveness, chemical stability, specific form of constituent particles of clay minerals in addition to the specific rheological properties, appropriate in different fluid media (Lima, 2001; Almeida, 2006; Santana et al. 2007; Brasileiro, 2010). Thus, the kaolin is an industrial mineral that has its properties in the expansion of its use, and having as an ally of its low cost compared to most competing materials (Silva, 2001). Worldwide use is spread across various industrial sectors with emphasis on the paper (covering and filling) that consumes $45 \%$, followed by ceramics (porcelain, white ceramic and refractory materials) $31 \%$ and the remaining $24 \%$ divided between ink, rubber, plastics and other (IBRAM, 2008).

In general, the mining of kaolin causes effects unwanted range that can be called externalities. These residues are in general, discharged on the environment, contaminating the ground and affecting the health of the population in the proximity of the producing regions. Some of these externalities: environmental change, land use conflicts, depreciation of surrounding properties, generation of degraded areas and urban traffic disturbances. 
These externalities generate conflicts with the community, which usually originate when the implementation of the project because the developer was not informed about the expectations, desires and concerns of the community living near the mining company.

In this way, it comes growing the concern of environmentalist with the great amount of wastes produced in the kaolin industry. The main problems relate to the amount of waste generated and air pollution. The kaolin waste generated are simply piled up on land companies for processing, thus occupying a large volume. As the waste disposal sites are not correct, when dried, turn to dust and the wind, spread, polluting the air, roads, streams, etc.. Figures 1 and 2 show the site of deposition of the residue from kaolin, a company located in Paraiba, Brazil, after its recovery as well as the location is not suitable for deposition of the same, which is close to villages and rivers, respectively.

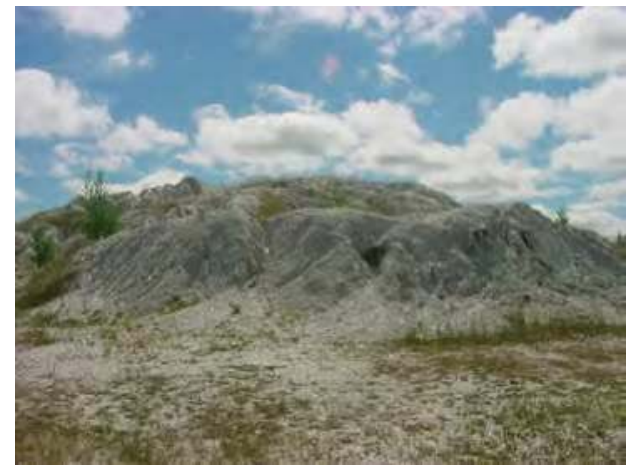

Fig. 1. View of the area used for disposal of waste generated during the processing of kaolin (Caulisa Company - City of Juazeirinho - Paraíba-Brazil)

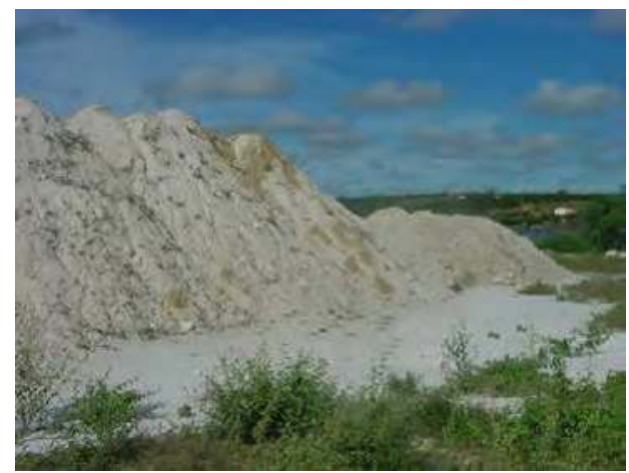

Fig. 2. Location of improper waste disposal (Caulisa Company - City of Juazeirinho Paraíba-Brazil)

Worldwide, millions of tons of kaolin waste, estimated at around $80 \%$ to $90 \%$ of the gross volume exploited, are produced each day in mining and mineral beneficiation.

One of aggravating of the kaolin residue deposit is that there is no exploitation, the waste is cumulative and cannot predict the future effects, since each batch received, twice its volume 
of waste is generated (SUDEMA, 2004). Another problem of this waste is that it is highly powdery, and its inhalation may cause lung disease and the skin contact causing dermatitis (Sakamoto, 2003).

The insertion of kaolin residue in the production cycle should represent an alternative option to recover these materials, which is interesting both in the environmental and health of the population next, as in economics. Recycling and reuse of kaolin residue are among the main alternatives in the quest for sustainable development, which aims to enable the economy of non-renewable raw materials and of energy, reducing the environmental impacts of waste in modern society.

The search for sustainable development makes the insertion of kaolin residue processing becomes the purposes of study in various areas of knowledge (Silva et al. 2001; Rocha, 2005, Menezes et al., 2007a, 2007b, 2007c; Resende, 2007), searching to minimize or even solve the environmental damage caused by these materials, either by optimization of the scanning method and storage or either by presentation of alternative re-use of waste as alternative raw material in various sectors.

As the processes of industrial processing, provide special features the kaolin for use in various industries, this means that the kaolin residue, has qualities that may be recycled or reused as a raw material for obtaining ceramic products.

The ceramic industry has demonstrated great potential for reuse of inorganic waste (Andreoli et al., 2002). The incorporation of waste from various industrial activities in ceramic products is an alternative technology to reduce environmental impacts and human adverse health effects caused by indiscriminate disposal of waste in nature (Özel et al. 2006; Pinatti et al, 2005).

Thus, the overall objective of this study was to investigate the viability of residual kaolin as an alternative raw material in obtaining mullite. Within this context, research will Facilitate the development of a technology practically nonexistent in Brazil and the world, which uses an alternative precursor, kaolin waste, which an alternative envisions the process with great potential for the synthesis of mullite. This would have positive social and economic consequences, both for generating industry of waste as for absorber industry, may promote a promising partnership between the privileged position of mullite, both domestically and abroad, and using waste as a raw material valued.

\section{Potential of kaolin residue as secondary raw materials}

The kaolin are those found in the place that formed by the action of weathering or hydrothermal action on rocks. The processing of this type of kaolin generates two types of waste. The waste first, generated by the wet process, which contains silica and others contaminants, resulting in amounts close to $70 \%$ by volume. The total volume of waste is very significant, since the improvement process has a yield of $30 \%$ of the total extracted from the deposit, ie, for each ton of raw material, less than one-third is taken advantage (these are the private data region, which can vary widely). The residue second is derived from the beneficiation of kaolin, separated in the previous step (about 30\%), underwent screening in ABNT $\mathrm{N}^{\mathrm{o}} 200$ mesh $(0.074 \mathrm{~mm})$. The material retained in the screening, called sludge, is the second residue, which was used in this study. This residue from processing of 
kaolin consists of minerals mica, quartz and feldspar, there is also the presence of kaolinite fraction whose amount is reduced depeding chiefly on the beneficiation process. The main product after sintering of kaolinite at high temperatures is the mullite ( Lima et al., 2001; Chen et al., 2000). The ceramic products of kaolinitic have desirable properties of hardness, translucency and strength development of the mullite crystals, regardless of the effect, their number and their size and shape. The kaolin waste have appropriate characteristics so that may be used for making alumina-silica refractory materials, as they have in their composition the kaolinite as principal clay mineral, which when subjected to high temperatures produces mullite.

The high prices of materials ceramic of mullite base, cause there is a need to use alternative materials that are environmentally, low cost and with local availability.

Thus, there is increasingly a constant search by the various industries and economic development activities coupled with environmental preservation. In order to take advantage of the kaolin residue in the many sectors involved in the ceramic industry, several studies have been developed in recent decades. Among them can mention:

- Flores \& Neves (1997), concluded that the methodology of alumina production through the use of tailings from the processing of kaolin is technically feasible, according to the parameters for the roasting, leaching and neutralization / crystallization adopted in his research.

- Miranda et al., (2000) studied the use of kaolin waste from industry benefited, with a view to the application as ceramic raw materials. Becoming evident that the possibility of using waste as raw material ceramic.

- Rocha (2005) studied the incorporation of the kaolin residue in the traces of mortar to be employed in construction activities. The results showed that traces of mortar containing kaolin residue are within the norms of ABNT, effecting thereby the feasibility of using this waste.

- Lima (2005) studied the potential of kaolin residue for use in plain concrete blocks with no structural function. The values of strength and absorption, obtained in all molded with the kaolin residue, are in accordance with the ABNT NBR NBR 7184/91 and $1211 / 91$ respectively, thus demonstrating the feasibility of using the kaolin residue.

- Neves et al. (2006) studied the incorporation of the kaolin residue in ceramic bodies aiming at its use in the production of blocks for construction. The results showed the use of waste as raw material for production of ceramic blocks.

- Andrade et al. (2009), in their studies, feature and studied the processing of the waste from the benefit of kaolin industry with addition of plastic clay in formulations for ceramic tiles. Preliminary results showed that the residue studied can be considered as raw material of great potential for industrial floors and ceramic tile.

\section{Using kaolin waste as raw material for obtaining mullite}

Mullite is one of the most important aluminum silicate ceramic technology, the only stable intermediate compound in the system $\mathrm{SiO}_{2}-\mathrm{Al}_{2} \mathrm{O}_{3}$, with the composition of $3 \mathrm{Al}_{2} \mathrm{O}_{3} \cdot 2 \mathrm{SiO}_{2}$, corresponding to $71.8 \mathrm{wt} \%$. The importance of technology, coupled with the occurrence rare in nature, emphasizes the importance of developing research and studies on the synthesis of mullite. 
Because it is rare and almost nonexistent in nature, due to training conditions, ie high temperatures and low pressures (Schneider et al. 2008; Schneider \& Komarneni, 2005, Vieira et al., 2007), present deposits are not enough to supply a growing market due to new applications found (Monteiro et al., 2004).

The mullite is perhaps one of the most important stages in both the traditional and advanced ceramics (Schneider et al. 2008; Juettner et al. 2007; Sola et al. 2006; Mazdiyasni et al., 1983). The exceptional scientific and technical importance of mullite can be explained on the basis of their characteristics, to be a stable crystalline phase from room temperature up to about $1880{ }^{\circ} \mathrm{C}$ at atmospheric pressure (Mileiko et al. 2009; Esharghawi et al. 2009; Schneider et al., 2008, Skoog et al., 1988), have in their properties the main reason for your application, such as low thermal expansion $\left(20 / 200{ }^{\circ} \mathrm{C}=4 \times 10^{-6} \mathrm{~K}^{-1}\right)$, low conductivity thermal $\left(\mathrm{k}=2.0 \mathrm{Wm}^{-1} \mathrm{~K}^{-1}\right)$, low density $\left(3.17 \mathrm{~g} / \mathrm{cm}^{3}\right)$, low dielectric constant $(\varepsilon=6.5$ at $1 \mathrm{MHz})$, excellent wear resistance and high resistance at temperatures suitable for use (Esharghawi et al. 2009; Schneider \& Komarneni, 2005; Schneider, 1994; Meng et al. 1983; Bartscher et al. 1999; Viswabaskaran et al., 2003), and the fact that the raw materials for its production (eg alumina, silica, aluminum silicates, sheet silicates rich in $\mathrm{Al}_{2} \mathrm{O}_{3}$, clays, etc.) are widely found in nature (Schneider et al., 2008).

Various routes like sol-gel, co-precipitation, hydrothermal processes and procedures for chemical vapor deposition and sintering are already used for the synthesis of this mineral. However, these typically use chemical precursors and high temperatures.

The number of studies showing the important methods for obtaining mullite, has been growing in recent years. The composition, purity of reagents, the synthesis processes used dictate the properties of all ceramic materials. Therefore, the choice of a certain synthesis process of mullite is a key step to obtain mullite with desired properties and applications. In order to reduce production costs, it is necessary, the use of precursors more economically viable, highlighting the potential kaolin waste for this function.

Studies conducted by our research group (Menezes et al., 2009a, 2009b; Brasileiro et al. 2006, 2008; Santana et al., 2007) aimed at recycling the waste from the processing of kaolin, showed that the kaolin residue has high levels of $\mathrm{SiO}_{2}$ and $\mathrm{Al}_{2} \mathrm{O}_{3}$, especially as a material of great potential for obtaining bodies that have properties for use in advanced ceramics, can be incorporated in ceramic formulations to obtain mullite.

This causes a secondary material to become a precursor suitable for obtaining a material that finds wide range of applications in conventional ceramics (porcelain, pottery, refractories, etc.) and advanced.

In general, it is necessary to observe the compositional variability of the kaolin residue with the quality of processing. Thus, each residue will have different potential for the synthesis, so that if the process is very efficient, or improved, there will be a reduction in the content of kaolinite, which likely will reduce the ability to produce mullite.

\section{Methodology used}

\subsection{Processing of kaolin residue}

The kaolin residue used in the development of the research was a result of primary processing of kaolin, extracted from the Borborema pegmatitic plain, located in the municipality of Juazeirinho-Paraíba - Brazil and donated by CAULISA Industry S/A. 
This kaolin residue was dried at a temperature of $110^{\circ} \mathrm{C}$ for 24 hours until constant weight. Soon after, was mill a unbundle type and climbs past ABNT $N^{\circ} 100(0.15 \mathrm{~mm})$ then stored in plastic bags. According to Castro (2008), made an analysis of the results with all parameters of the material leached and dissolved, the residue from the beneficiation of kaolin, indicate that they are below the standardized (ABNT NBR 10004 (2004)), which fits this residue as type B class II waste - inert waste.

A small amount of residue powder kaolin, sieved in ABNT $\mathrm{N}^{\circ} 200(0.074 \mathrm{~mm})$, was pressed in cylindrical shape, so this required by the equipment used in research. The sample of the kaolin residue, was analyzed by XRF in Shimadzu (EDX-900) thus determining its chemical composition (Table 1). Chemical analysis provides key data of great scientific and industrial use, although not a full evaluation of the mineralogical composition and physico-chemical and technological. The residue also sifted through sieve $\mathrm{N}^{0} 200$ ABNT $(0.074 \mathrm{~mm})$, was submitted to phase identification, carried out by X-ray diffraction, using an apparatus manufactured by Shimadzu, model XRD-6000 with CuKa radiation $(40 \mathrm{kV} / 40 \mathrm{~mA})$ at a speed of $2^{\circ} / \mathrm{min}$ from $15^{\circ}$ to $60^{\circ}$.

\subsection{Formulation of compositions for obtaining specimens}

Being a careful and complex step in the production process of ceramic materials, the formulation of ceramic masses requires a prior knowledge of the raw materials that will be employed, seeking to establish a proper ratio of chemical raw materials for that particular phase is obtained. At this stage, took into account the chemical analysis of Alumina A1000SG, courtesy company Alcoa Industrial Chemicals Division, USA. The formulations (Table 2) of the ceramic bodies was performed with the aid of the REFORMIX 2.0, DEVELOPED BY THE Federal University of São Carlos - São Paulo - Brazil, being released data from the established results of chemical analysis of raw materials (kaolin residue), taking into account the desired stoichiometry of the mullite $\left(3 \mathrm{Al}_{2} \mathrm{O}_{3} \cdot 2 \mathrm{SiO}_{2}\right)$.

\subsection{Process of forming and firing of the specimens}

Formulated ceramic masses, they were mixed in ethyl alcohol (as described in the literature (Chen \& Tuan, 2001)), together with the dispersing agent (PABA) and lubricant (oleic acid) in an alumina ball mill for $2 \mathrm{~h}$. After the mixing step, the masses were dried in an oven $\left(110^{\circ}\right.$ C), unbundle and passed in sieve ABNT $\mathrm{N}^{\circ}$. $100(0.15 \mathrm{~mm})$. Then, the masses were moistened with $8 \%$ water, and thus stored for 24 hours for a better distribution of moisture. In step forming was used pressing process where the bodies of the test piece were conformed by uniaxial pressing of $35 \mathrm{MPa}$ and dimensions (50 $\mathrm{mm} \times 8 \mathrm{~mm} \times 6 \mathrm{~mm}$ ) in a hydraulic press (SCHWING / Siwa). The piece test bodies was dried in an oven at $110{ }^{\circ} \mathrm{C}$ for 24 hours and then subjected to the process of burning in a conventional electric oven (Maitec / Flyever / FE $50 \mathrm{rpm}$ ) at a temperature ranging from $1400{ }^{\circ} \mathrm{C}$ to $1600{ }^{\circ} \mathrm{C} / 2 \mathrm{~h}$ and heating rate of $5^{\circ} \mathrm{C} / \mathrm{min}$ in air atmosphere.

Since there is a growing interest in the use of microwave energy for processing materials at high temperatures, the specimens were subjected to sintering process in a domestic microwave oven for comparison. The oven had a frequency of $2.45 \mathrm{GHz}$, and the specimens were sintered in powers of 80 and $90 \%$ (output power of $1.44 \mathrm{~kW}$ and $1.62 \mathrm{~kW}$, respectively) and irradiation times ranging from 10, 15, 20 and $25 \mathrm{~min}$. The atmosphere of the microwave 
oven was the air. Figures 3 and 4 show the conventional and microwave oven, respectively, used in burning of the specimens.

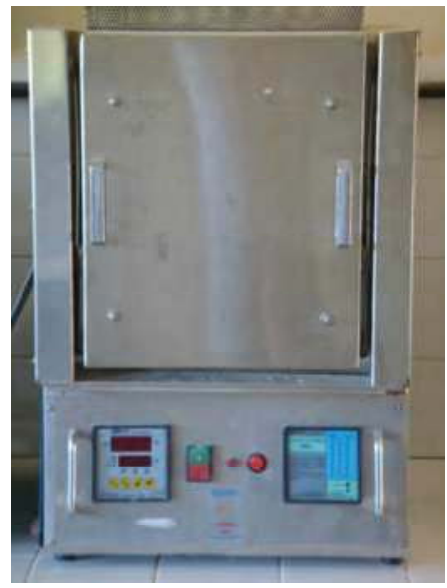

Fig. 3. Conventional oven used in the burning of the specimens

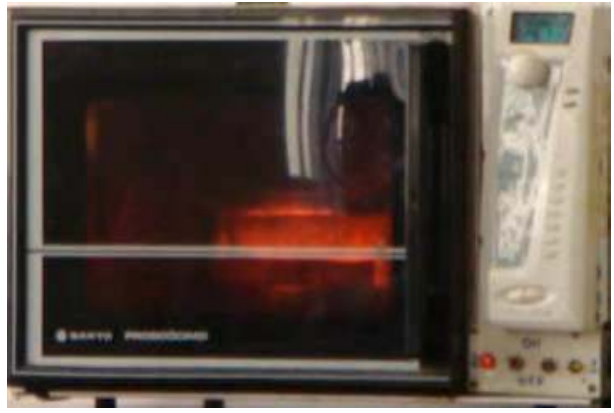

Fig. 4. Domestic microwave oven used in research

\subsection{Tests for mineralogical characterization of the specimens}

After sintering of the bodies, it was ground in porcelain mortar and sifted through sieve $\mathrm{N}^{\circ}$. $200 \mathrm{ABNT}(0.074 \mathrm{~mm})$ and then submitted to phase identification, performed by diffraction X-rays, using an apparatus manufactured by Shimadzu, model XRD-6000 with CuKa radiation $(40 \mathrm{kV} / 40 \mathrm{~mA})$, pertaining to Department of Materials UFCG, the rate of $2 \% \mathrm{~min}$ from $15^{\circ}$ to $60^{\circ}$. The interpretation was performed by comparison with standards contained in Shimadzu software.

The bodies of the test piece were also subjected to microstructural characterization, performed in a scanning electron microscope, Phillips, model XL30FEG from the Department of Materials Engineering, Federal University of Paraíba. First analyzed the fracture surface and then the samples were polished and attacked with HF (10\%) to remove the vitreous of the specimens and observed the morphology of mullite grains formed. For these tests, the samples were coated with a gold film using a vacuum evaporator. 


\section{Results}

Preliminary tests made with the kaolin residue (Castro, 2008) showed that all parameters of the material are dissolved and leached below the standardized (ABNT NBR 10004 (2004)), which fits this residue as the residue class II type B - inert waste.

Figure 5 shows the diffractogram of the kaolin residue. From the XRD pattern verified that the kaolin residue has the following mineralogical phases: kaolinite characterized by interplanar distances of 7.07 and $3.56 \AA$, a small amount of mica characterized by 10.04 and $4.97 \AA$, and also quartz characterized by 2.66 and $2.08 \AA$.

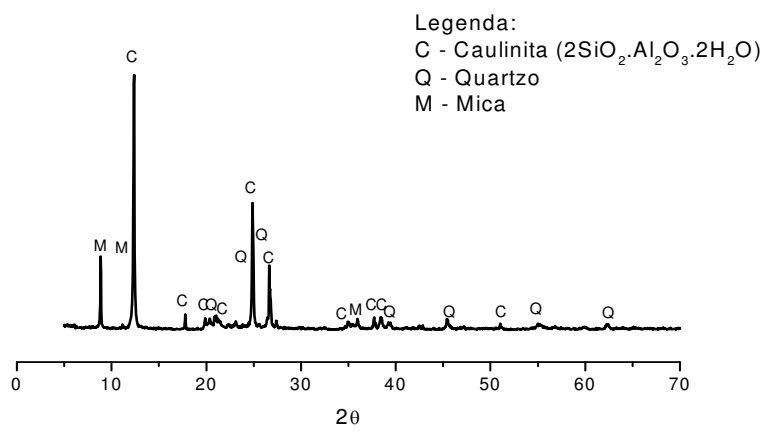

Fig. 5. XRD of the residue of kaolin

Figure 6 shows the test results for the particle size distribution of the kaolin residue used in this work.

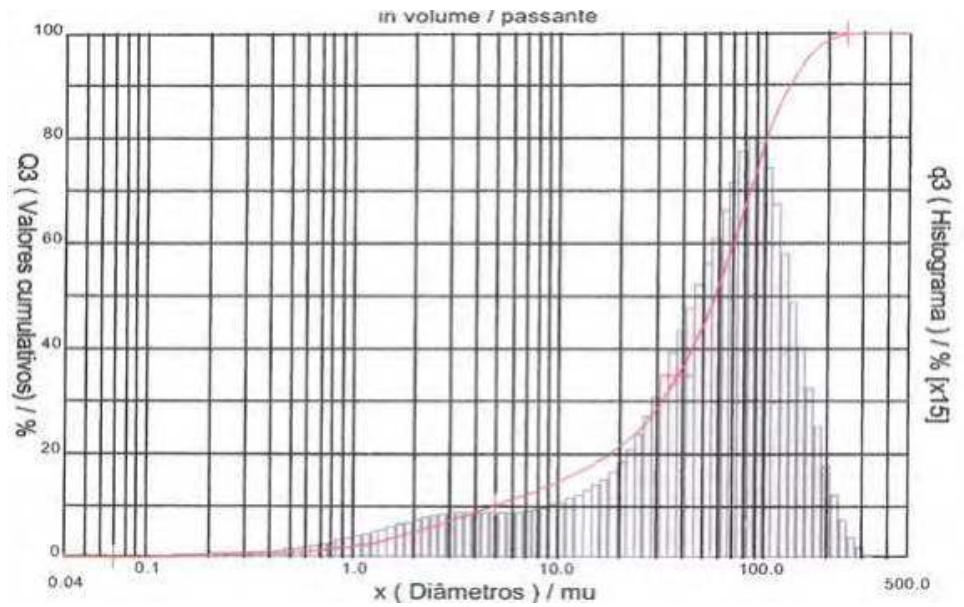

Fig. 6. Particle size distribution of the residual kaolin

The residue has a particle size of $54.35 \mathrm{~m}$ is a relatively broad size distribution, with $\mathrm{D} 10=5 \mathrm{~mm}, \mathrm{D} 50=58 \mu \mathrm{m}, \mathrm{D} 90=130 \mu \mathrm{m}$, with a high fraction of particles with equivalent diameter greater than $40 \mu \mathrm{m}$. 
The chemical composition of the kaolin residue and alumina used in the course of this research is shown in Table 1.

The development of formulations used in this work was based on chemical analysis of raw materials.

It can be seen from Table 1 that the kaolin residue in its composition showed $52.68 \%$ of silicon oxide and $33.57 \%$ alumina oxide, therefore, due to high contents of $\mathrm{SiO}_{2}$ and $\mathrm{Al}_{2} \mathrm{O}_{3}$, used to be used in obtaining mullite.

Alumina has analyzed high purity, $99.8 \%$ and was added to the kaolin residue in order to react with the glassy phase formed at high temperatures and thus form the secondary mullite.

The mullite, most commonly produced from the solid state reaction of powdered a-alumina and silica, is the mullite of composition 3:2, according to published data. The mullite present in this composition has been well studied with respect to the method of synthesis, thermal and mechanical properties (Yu et al., 1998).

Taking into account that the reaction $2 \mathrm{SiO}_{2} \cdot \mathrm{Al}_{2} \mathrm{O}_{3} \cdot 2 \mathrm{H}_{2} \mathrm{O}+2 \mathrm{Al}_{2} \mathrm{O}_{3} \rightarrow 3 \mathrm{Al}_{2} \mathrm{O}_{3} \cdot 2 \mathrm{SiO}_{2}+$ $2 \mathrm{H}_{2} \mathrm{O}$ occurs by a mixture of kaolinite and alumina during sintering, and assuming that the silica $\left(\mathrm{SiO}_{2}\right)$ in kaolinite reacts completely with the alumina $\left(\mathrm{Al}_{2} \mathrm{O}_{3}\right)$ to form mullite $($ Chen et al., 2000), the kaolin residue that showed $52.68 \%$ of $\mathrm{SiO}_{2}$, requires an excess of alumina for the reaction with silica, present in the residue, can result in mullite.

\begin{tabular}{|c|c|c|c|c|c|c|c|c|c|}
\hline Raw materials & $\mathrm{SiO}_{2}$ & $\mathrm{Al}_{2} \mathrm{O}_{3}$ & $\mathrm{Fe}_{2} \mathrm{O}_{3}$ & $\mathrm{Na}_{2} \mathrm{O}$ & $\mathrm{K}_{2} \mathrm{O}$ & $\mathrm{TiO}_{2}$ & $\mathrm{CaO}$ & $\mathrm{MgO}$ & $*$ L.I \\
\hline Kaolin residue & 52.68 & 33.57 & 0.93 & 0.08 & 5.72 & 0.12 & ---- & ----- & 6.75 \\
\hline $\begin{array}{c}\text { Alumina A1000 } \\
\text { SG }\end{array}$ & 0.03 & 99.8 & 0.02 & 0.06 & ----- & ----- & 0.02 & 0.03 & ----- \\
\hline
\end{tabular}

Table 1. Analysis of chemical constituents (in \%) of the residue of kaolin and alumina. * L.I Loss Ignation

Table 2 shows the compositions made of ceramic masses studied in this research.

\begin{tabular}{|c|c|c|c|c|c|}
\hline Raw materials & \multicolumn{5}{|c|}{ Formulations (proporcion in mass weight \%) } \\
\hline & 1 & 2 & 3 & 4 & 5 \\
\hline Kaolin residue & 54 & 50 & 46 & 42 & 38 \\
\hline Alumina & 46 & 50 & 54 & 58 & 62 \\
\hline
\end{tabular}

Table 2. Formulations of mass (weight $\%$ )

Compositions were formulated with lower and higher levels of alumina, so that these formulations to stay within the stoichiometry of the mullite to be reached.

Table 3 presents the chemical composition (in \%) of the compositions performed by XRF. 


\begin{tabular}{|l|c|c|c|c|c|c|c|c|c|c|}
\hline Sample & $\mathrm{SiO}_{2}$ & $\mathrm{Al}_{2} \mathrm{O}_{3}$ & $\mathrm{Fe}_{2} \mathrm{O}_{3}$ & $\mathrm{CaO}$ & $\mathrm{NaO}_{2}$ & $\mathrm{P}_{2} \mathrm{O}_{5}$ & $\mathrm{~K}_{2} \mathrm{O}$ & $\mathrm{MnO}$ & $\mathrm{TiO}_{2}$ & P.F \\
\hline Form. 1 & 28,46 & 64,01 & 0,51 & 0,01 & 0,07 & --- & 3,09 & --- & --- & 3,64 \\
\hline Form. 2 & 26,35 & 66,68 & 0,47 & 0,01 & 0,07 & --- & 2,86 & --- & --- & 3,37 \\
\hline Form. 3 & 24,25 & 69,33 & 0,44 & 0,01 & 0,07 & --- & 2,63 & --- & --- & 3,10 \\
\hline Form. 4 & 22,14 & 71,98 & 0,40 & 0,01 & 0,07 & --- & 2,40 & --- & --- & 2,83 \\
\hline Form. 5 & 20,03 & 74,63 & 0,37 & 0,01 & 0,07 & --- & 2,17 & --- & --- & 2,56 \\
\hline
\end{tabular}

Table 3. Chemical composition of masses by XRF (in \%)

Analyzing the values in Table 3, it was found that the percentage of silica are in the range from 20 to $28 \%$ and the percentage of alumina in a range from 64 to $75 \%$, indicating that the proportions of the oxides are approaching values for obtaining secondary mullite (3Al2O3. $2 \mathrm{SiO} 2)$. These proportions of oxides also show that the formulation 2 , was very close to the stoichiometry of the mullite to be reached 3:2 (3Al2O3. 2SiO2), the formulation 1 has less alumina and the formulas 3,4 and 5, present with more alumina, values which grow gradually.

\subsection{Microstructural features of the specimens sintered in a conventional oven}

The XRD pattern of samples sintered in conventional oven at temperatures ranging from 1400 to $1600{ }^{\circ} \mathrm{C}$, with a landing-burning $2 \mathrm{~h}$, are shown in Figures 7, 8, 9, 10 and 11 with the formulations 1, 2, 3, 4 and 5, respectively.

Through $\mathrm{XRD}$, in all compositions, observed the presence of the following phases: mullite, quartz, cristobalite and alumina. At the temperature of $1400{ }^{\circ} \mathrm{C}$ the crystalline phases observed were mullite, quartz and alumina. At temperatures of $1450{ }^{\circ} \mathrm{C}$ to $1550{ }^{\circ} \mathrm{C}$ the crystalline phases were mullite, quartz, alumina and cristobalite. The appearance of cristobalite is due to the crystallization of vitreous silica. The intensity of the peaks of quartz and cristobalite, virtually disappear with increasing sintering temperature, while the intensities of the characteristic peaks of mullite increases with increasing sintering temperature.

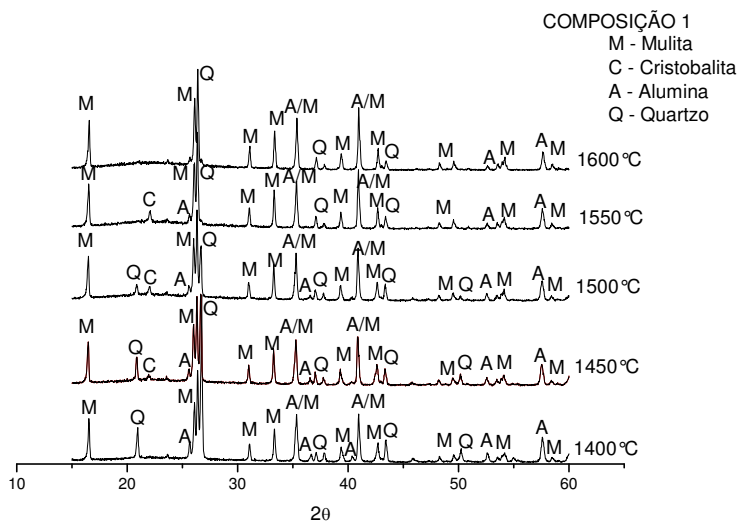

Fig. 7. XRD of samples of formulation 1 


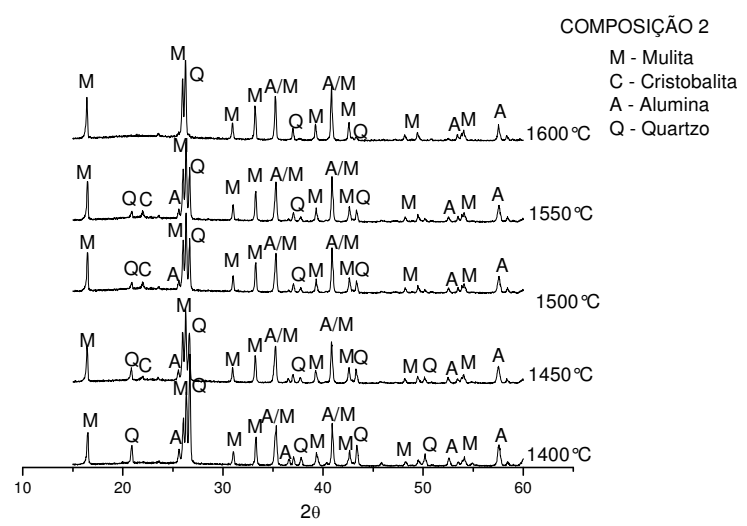

Fig. 8. XRD of samples of formulation 2

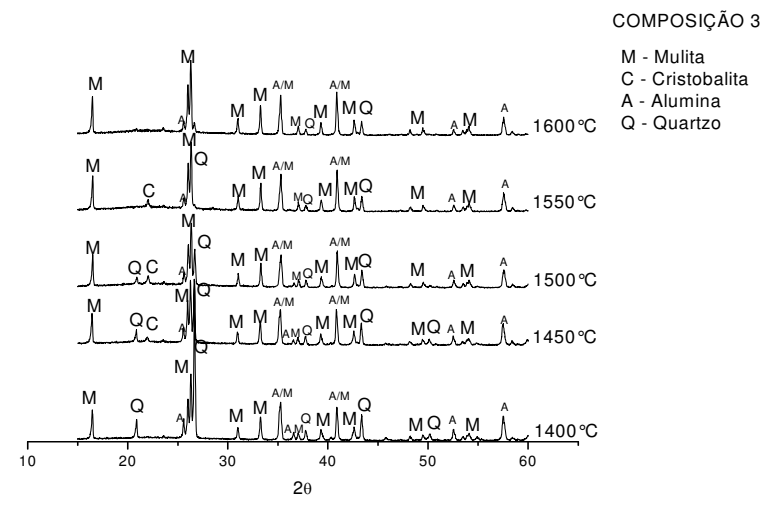

Fig. 9. XRD of samples of formulation 3

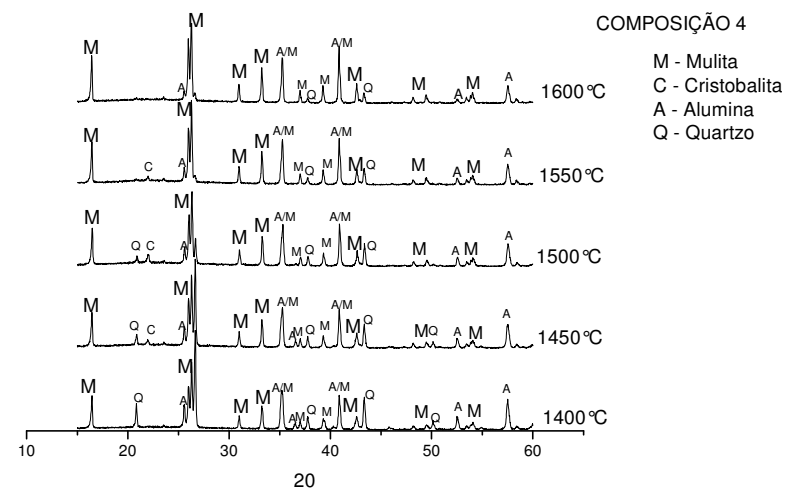

Fig. 10. XRD of samples of formulation 4 


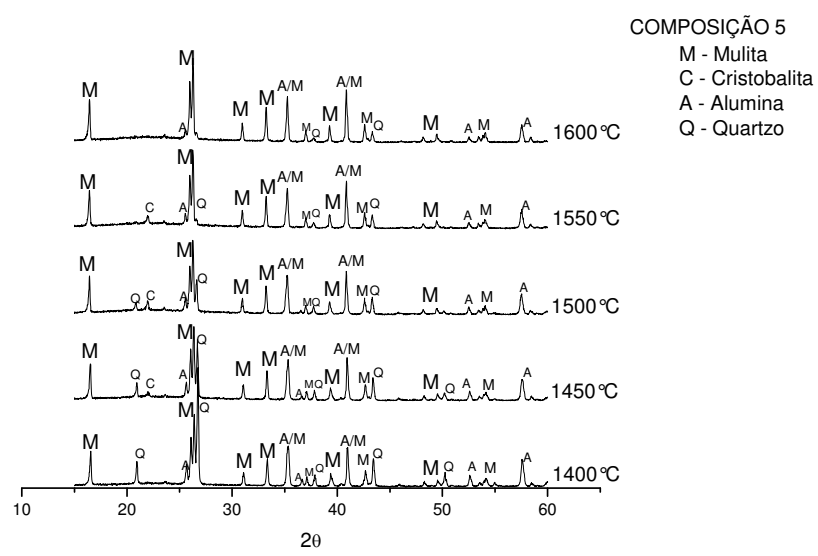

Fig. 11. XRD of samples of formulation 5

Figs 7 and 8, the which formulations have higher amounts of $\mathrm{SiO}_{2}$, show alumina peaks a lesser degree when compared with other compositions, on the other hand the peaks of quartz present with greater intensity. According to Chen et al. (2000), the addition of $\mathrm{Al}_{2} \mathrm{O}_{3}$ can reduce the amount of glassy phase and increase the amount of mullite. This statement was confirmed by XRD patterns of formulations 3, 4 and 5 .

For all compositions, observed that in $1600{ }^{\circ} \mathrm{C}$, there was not a complete reaction of mulitization, became evident that even the formulation 2 (stoichiometrically correct) it is necessary a further increase in sintering temperature to occurs a complete mulitization.

Figures 12 ( $\mathrm{a}$ and $\mathrm{b}), 13$ ( $\mathrm{a}$ and $\mathrm{b}$ ), 14 ( $\mathrm{a}$ and $\mathrm{b}), 15$ ( $\mathrm{a}$ and $\mathrm{b}$ ) and 16 ( $\mathrm{a}$ and $\mathrm{b}$ ) show the microstructures of the formulations $1,2,3,4$ and 5 sintered in a conventional oven at temperatures of 1500 and $1550{ }^{\circ} \mathrm{C}$, respectively.

Observed from the micrographs that the sintering provided the formation of a heterogeneous microstructure characterized by the formation of primary mullite, which is presented in the form of clusters of small crystals; secondary mullite, which is presented in

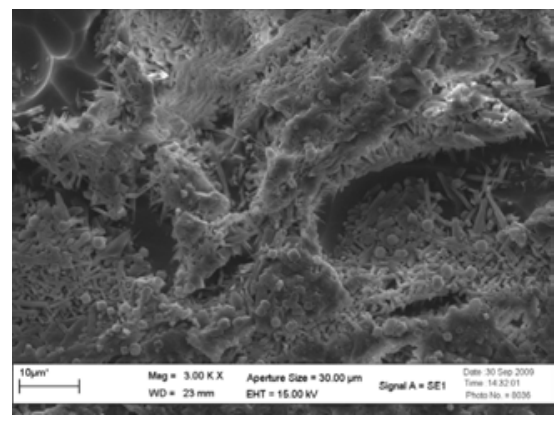

(a)

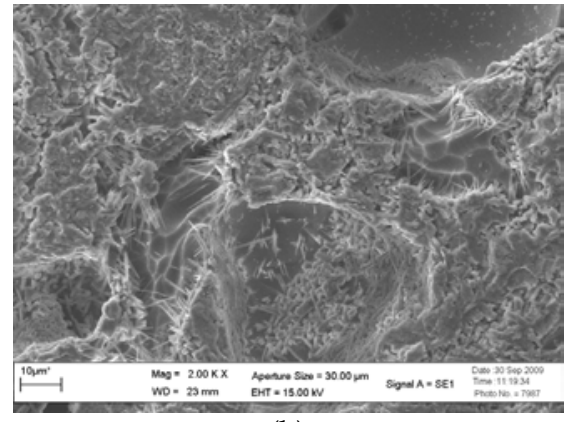

(b)

Fig. 12. (a and b) - Microstructure of formulation 1 sintered in conventional oven at temperatures of $1500^{\circ} \mathrm{C}(\mathrm{a})$ and $1550{ }^{\circ} \mathrm{C}(\mathrm{b})$ 


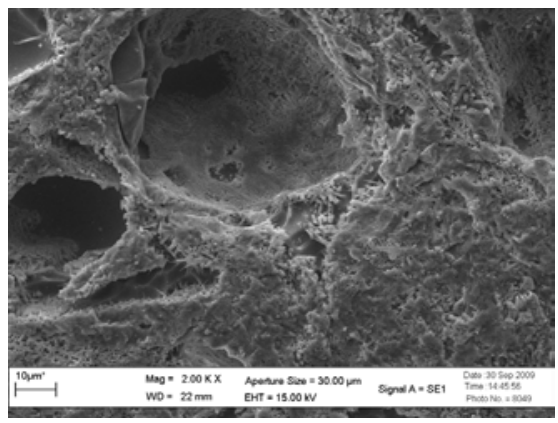

(a)

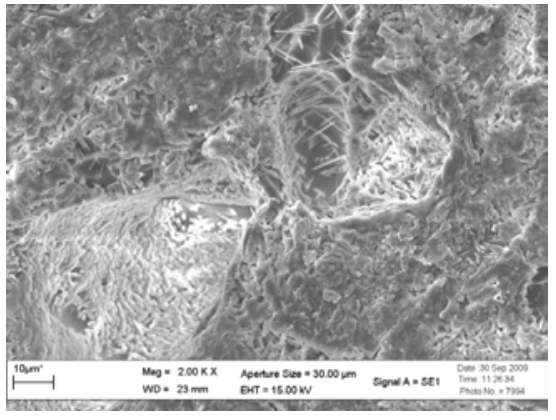

(b)

Fig.13. (a and b) - Microstructure of formulation 2 sintered in conventional oven at temperatures of $1500^{\circ} \mathrm{C}(\mathrm{a})$ and $1550{ }^{\circ} \mathrm{C}(\mathrm{b})$

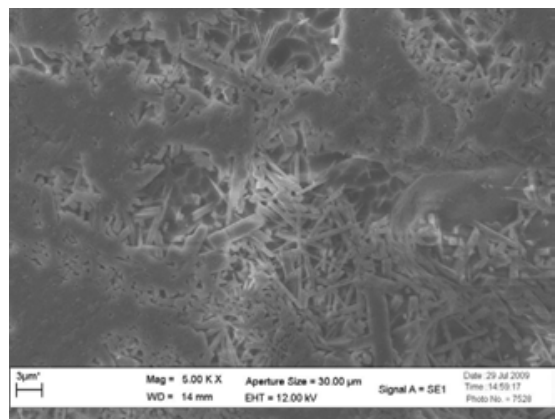

(a)

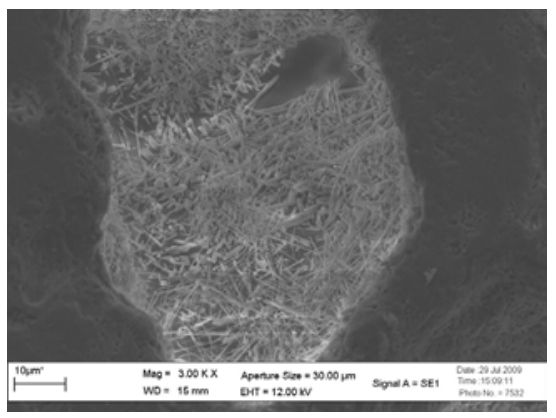

(b)

Fig. 14. (a and b) - Microstructure of formulation 3 sintered in conventional oven at temperatures of $1500{ }^{\circ} \mathrm{C}(\mathrm{a})$ and $1550{ }^{\circ} \mathrm{C}(\mathrm{b})$

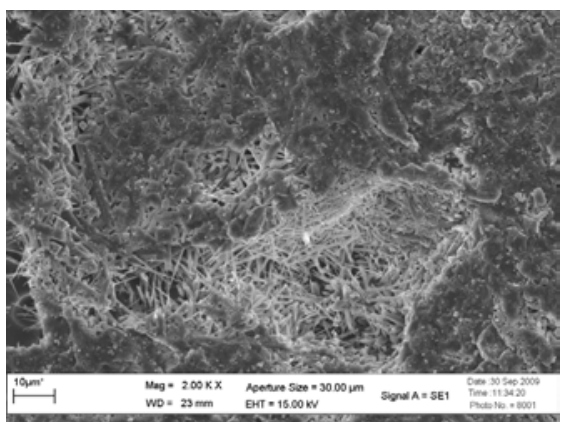

(a)

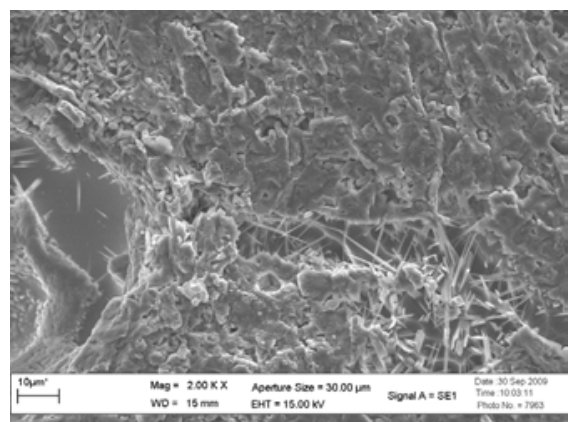

(b)

Fig. 15. ( $a$ and $b$ ) - Microstructure of formulation 4 sintered in conventional oven at temperatures of $1500{ }^{\circ} \mathrm{C}(\mathrm{a})$ and $1550{ }^{\circ} \mathrm{C}(\mathrm{b})$ 


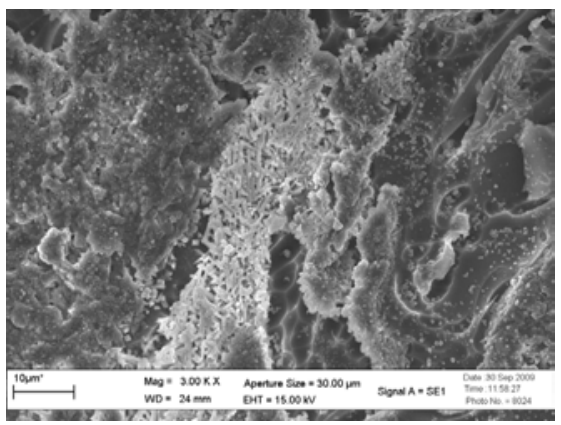

(a)

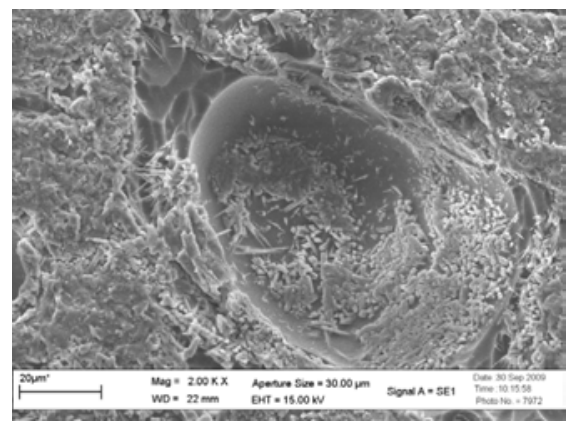

(b)

Fig. 16. ( $a$ and $b$ ) - Microstructure of formulation 5 sintered in conventional oven at temperatures of $1500{ }^{\circ} \mathrm{C}(\mathrm{a})$ and $1550{ }^{\circ} \mathrm{C}(\mathrm{b})$

the form of long crystals and the presence pore. The formation of secondary mullite case of transient liquid phase, which happens to precipitation of crystals, ie the added alumina dissolves in the glass phase and mullite is precipitated. At $1500{ }^{\circ} \mathrm{C}$ was observed to obtain mullite, indicating that this system is a decrease in the eutectic point, with respect to the phase diagram composed of $\mathrm{SiO}_{2}$ and $\mathrm{Al}_{2} \mathrm{O}_{3}$. Also in $1500^{\circ} \mathrm{C}$, observed the formation of both the primary mullite, which is presented in the form of clusters of small crystals, while the secondary mullite, is presented in the form of elongated crystals, like needles. The temperature rise from 1500 to $1550{ }^{\circ} \mathrm{C}$ provided the formation of a larger amount of secondary mullite and an increase in structure of the grains, making them more elongated, and the more intense the stretch as the temperature increased to $1550{ }^{\circ} \mathrm{C}$. According to Iqbal \& Lee (1999), the higher viscosity of the glassy phase favors the growth of crystals of mullite and also the continued growth in the size of the crystals indicates the possibility of primary mullite transformation of secondary mullite.

\subsection{Microstructural features of the specimens sintered in a microwave oven}

In domestic microwave oven used in the research, it was not possible to determine the temperature of use in the powers used, since it does not have provision for this. The XRD pattern of samples sintered in a microwave oven for 10, 15, 20 and 25 minutes are shown in Figures 18 (a e b), 19 (a e b), 20 (a e b), 21 (a e b) and 22 (a e b) with the formulations 1, 2 , 3, 4 and 5 , respectively. These XRD patterns provide more information about the nature of synthesis from the microwave energy.

From the XRD patterns above can be seen that the formulation 1 (Fig. 17), subjected to $80 \%$ power and irradiation time of $15 \mathrm{~min}$, began to show peaks of mullite into sharper focus when compared with other formulations. This formulation (see Table 3) presents a greater amount of $\mathrm{SiO}_{2}$, which form in the sintering probably a greater amount of liquid phase, which would imply an acceleration in the reaction of formation of mullite. The formation of mullite was evident when the power used was $90 \%$ from $10 \mathrm{~min}$. The peaks also show the presence of quartz and alumina. 
Formulation 2 (Fig. 18), which has chemical composition closer to stoichiometry of mullite, sintered at $90 \%$ power and irradiation time of $20 \mathrm{~min}$, presented in a manner relative to the intensity of the peaks, an amount greater formation of mullite, compared to formulation 1 . Probably a slightly larger amount of alumina present in this sample, when compared to formulation 1, enabled a greater reaction between alumina and glassy phase for the formation of mullite.

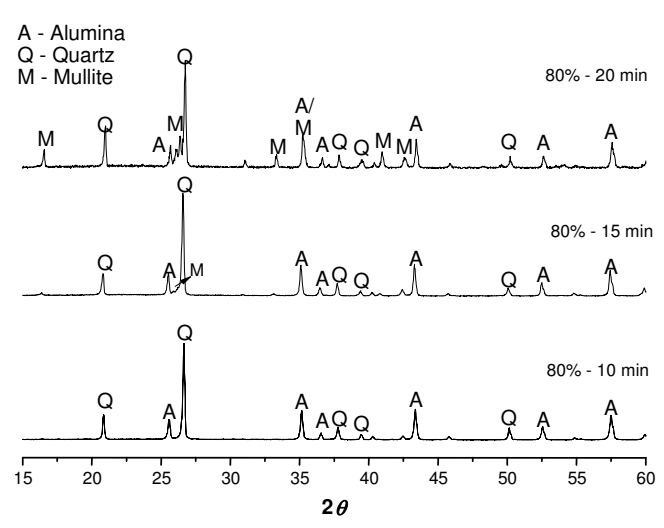

(a)

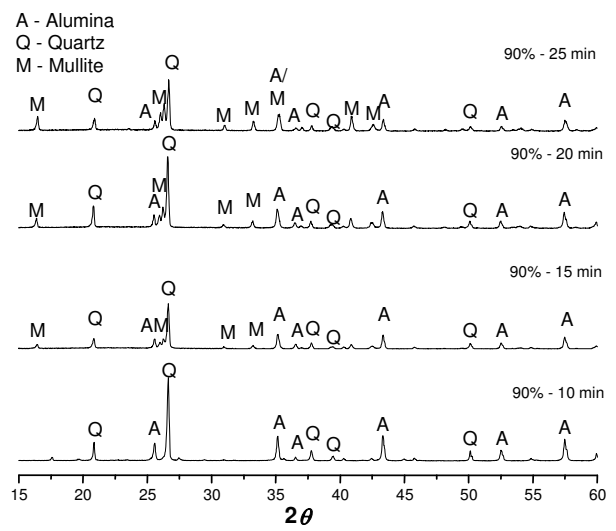

(b)

Fig. 17. ( $a$ and $b$ ) - XRD patterns of formulation 1 sintered in microwave at $80 \%$ power (a) (in times of 10, 15 and 20 minutes) and the power of $90 \%$ (b) (in times of 10, 15, 20 and 25 minutes)

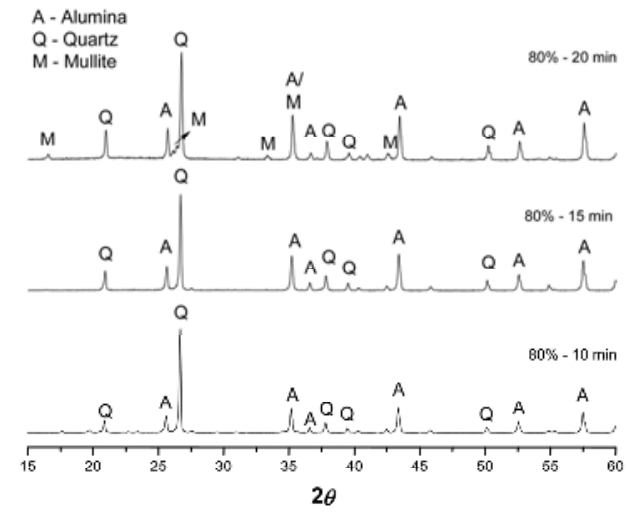

(a)

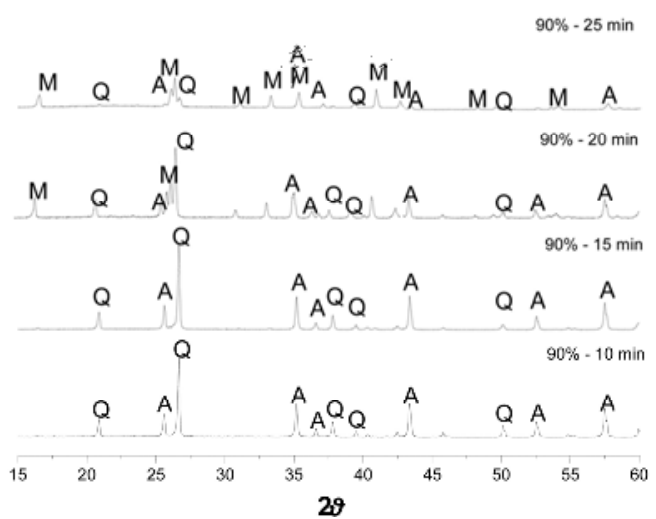

(b)

Fig. 18. (a and b) - XRD patterns of formulation 2 sintered in microwave at $80 \%$ power (a) (in times of 10, 15 and 20 minutes) and the power of 90\% (b) (in times of 10, 15, 20 and 25 minutes) 
Formulation 3 (Fig. 19), with amount of alumina most than formulation 2, did not show the formation of mullite in equal proportions, when compared with formulations 1 and 2 when sintered in the power of $90 \%$ and time $20 \mathrm{~min}$, what can this associated with a likely absence of liquid phase.

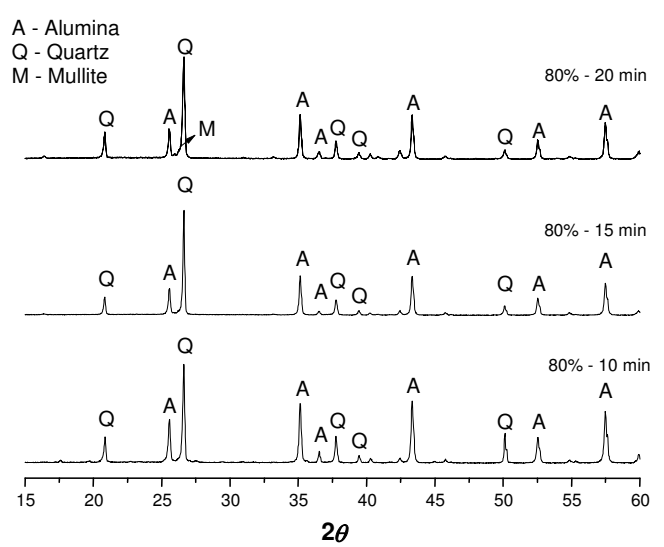

(a)

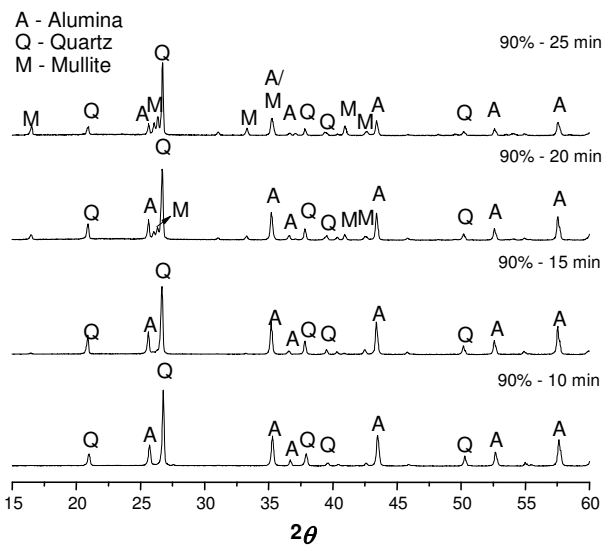

(b)

Fig. 19. ( $a$ and $b$ ) - XRD patterns of formulation 3 sintered in microwave at $80 \%$ power (a) (in times of 10, 15 and 20 minutes) and the power of 90\% (b) (in times of 10, 15, 20 and 25 minutes)

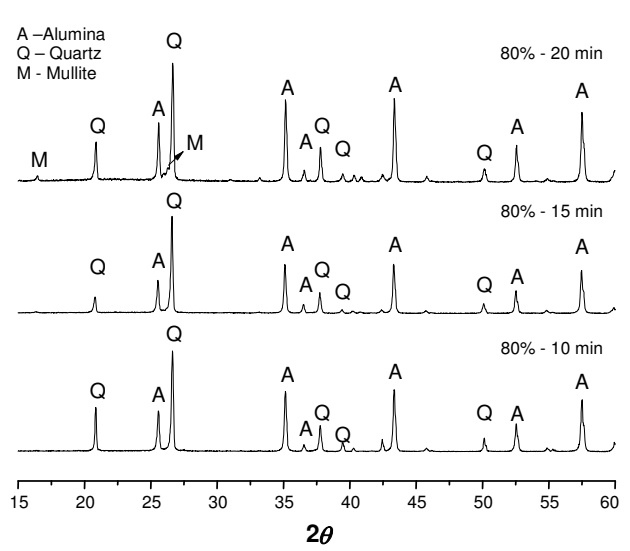

(a)

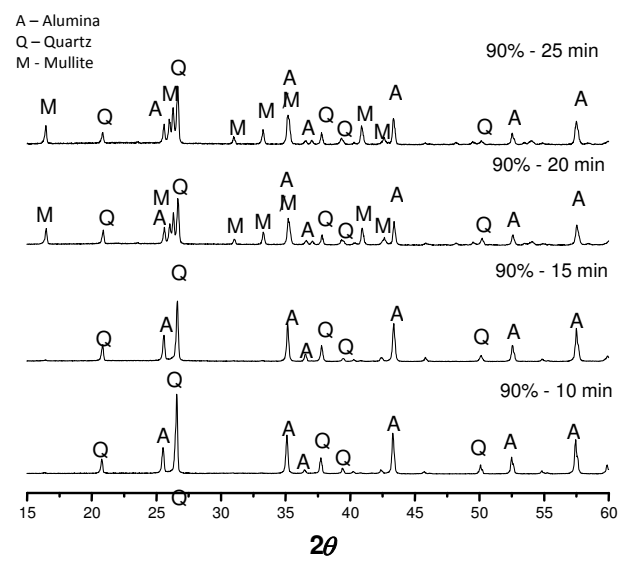

(b)

Fig. 20 ( $a$ and $b$ ) - XRD patterns of formulation 4 sintered in microwave at $80 \%$ power (a) (in times of 10, 15 and 20 minutes) and the power of $90 \%$ (b) (in times of 10, 15, 20 and 25 minutes) 


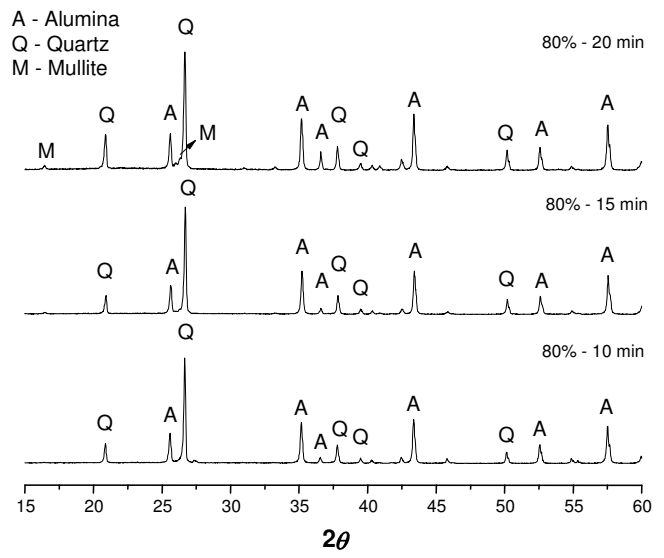

(a)

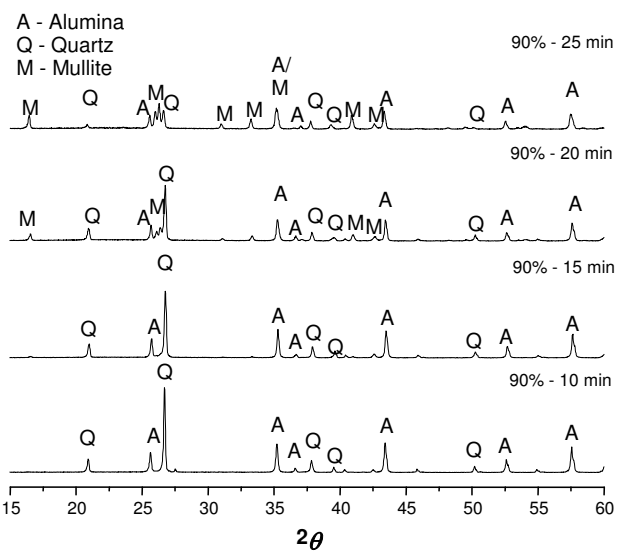

(b)

Fig. 21. ( $a$ and $b$ ) - XRD patterns of formulation 5 sintered in microwave at $80 \%$ power (a) (in times of 10, 15 and 20 minutes) and the power of 90\% (b) (in times of 10, 15, 20 and 25 minutes)

The formulations 4 and 5 had similar behaviors when sintered at a power of $90 \%$ and times $20 \mathrm{~min}$. The XRD patterns showed peaks of mullite formation, indicating that there was a reaction between the liquid phase and alumina, and that perhaps this composition range, the reaction went to the side of the eutectic phase diagram of the system $\mathrm{Al}_{2} \mathrm{O}_{3}-\mathrm{SiO}_{2}$ favoring the formation of mullite.

In general, the formulations subjected to $90 \%$ power and times of 25 minutes, increased the peaks corresponding to formation of mullite and on the other hand, there was a decrease in the number of peaks of quartz in the amount of alumina peaks.

Analyzing powers and times used, it can be said that the power of $90 \%$ and 25 min time favored the formation and growth of the mullite peaks at all compositions, and these processing parameters were still insufficient for a total reaction between alumina and silica to form mullite, since the XRD patterns indicate the presence of quartz and alumina. Figures 22 ( $a, b$ and c), 23 ( $a, b$ and c), 24 ( $a, b$ and c), 25 ( $a, b$ and $c)$ and 26 ( $a, b$ and c) show the microstructures of the formulations $1,2,3,4$ and 5 , sintered in a microwave oven with times of 20 and 25 minutes and the power of $80 \%$ and $90 \%$.

It can be seen from the figures (22-26), the main phases found in the samples are mullite primary, secondary mullite, quartz particles and pores. The quartz grains are surrounded by cracking due to the large difference between the coefficient of thermal expansion of quartz $\left(\alpha \approx 23 \times 10^{-6} \mathrm{~K}^{-1}\right)$ and glassy phase $\left(\alpha \approx 3 \times 10^{-6} \mathrm{~K}^{-1}\right)$. The primary mullite is present in the form of compact aggregates of small crystals. It is also observed that the sintered samples, in the power of $80 \%$ and time 20 minutes, show the formation of needles, proving the acquisition of secondary mullite. The process of formation of secondary mullite needles continues and becomes even more evident when the samples are sintered in the power of $90 \%$ and time 20 minutes. The samples sintered in $90 \%$ power and time of 25 minutes revealed a significant degree of recrystallization and a reduction in the appearance of needles. Similar results of 


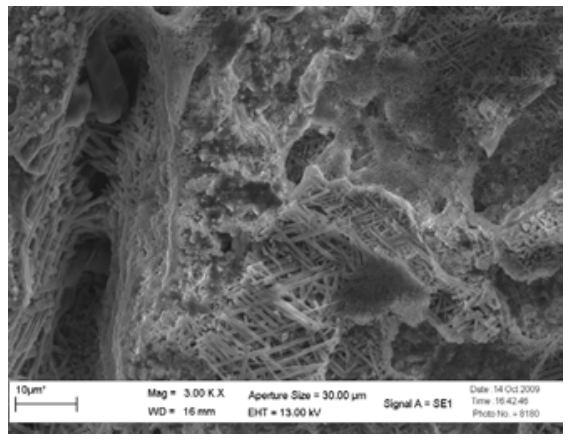

(a) $20 \mathrm{~min}$ in the power of the $80 \%$

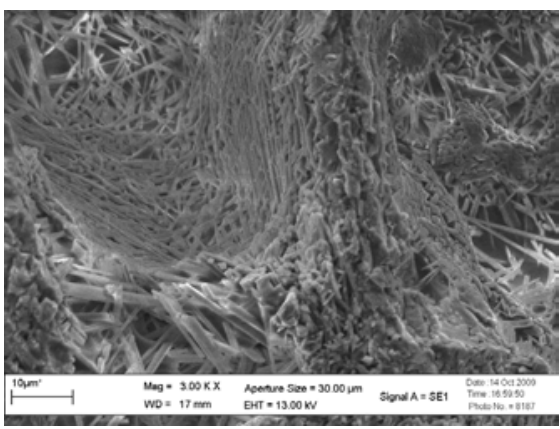

(b) $20 \mathrm{~min}$ in the Power of the $90 \%$

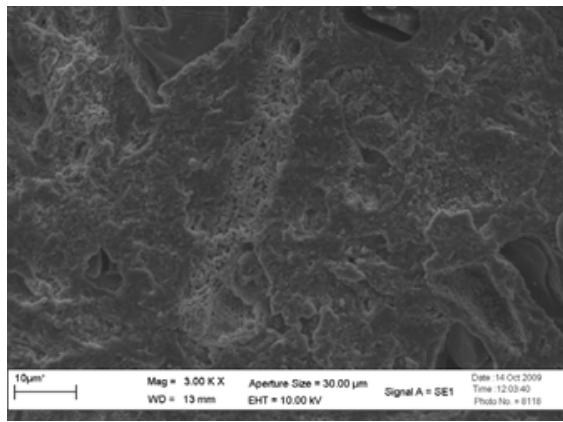

(c) $25 \mathrm{~min}$ in the power of the $90 \%$

Fig. 22. (a, b and c) - Microstructure of formulation 1 sintered in microwave power of $80 \%$ and $90 \%$ and times of 20 and 25 minutes 


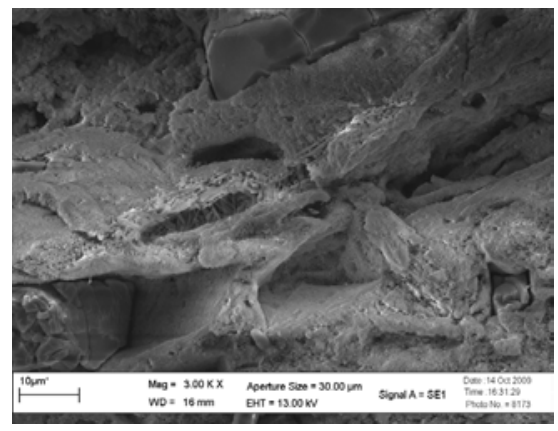

(a) $20 \mathrm{~min}$ in the Power of the $80 \%$

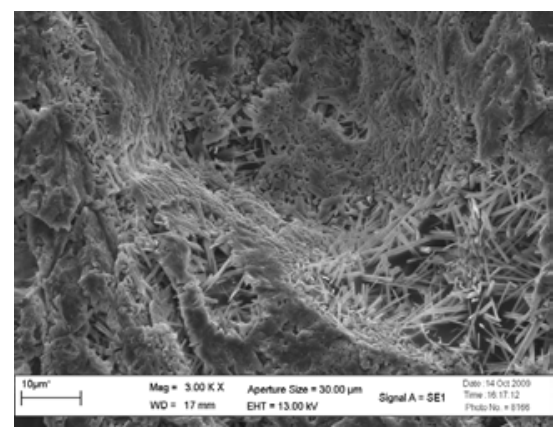

(b) $20 \mathrm{~min}$ in the Power of the $90 \%$

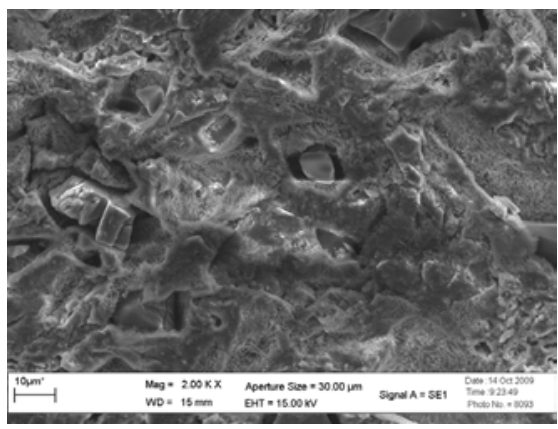

(c) $25 \mathrm{~min}$ in the power of the $90 \%$

Fig. 23. ( $a, b$ and c) - Microstructure of formulation 2 sintered in microwave power of $80 \%$ and $90 \%$ and times of 20 and 25 minutes 


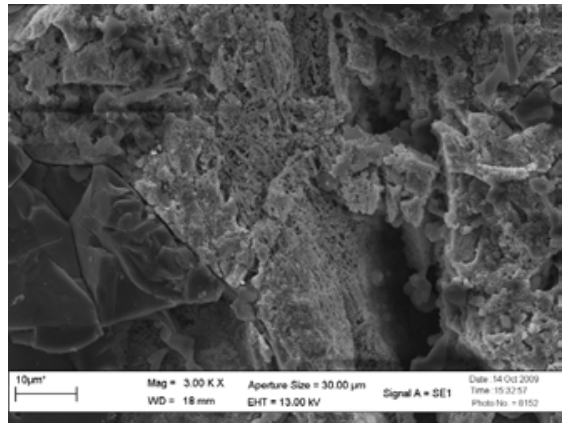

(a) $20 \mathrm{~min}$ in the power of the $80 \%$

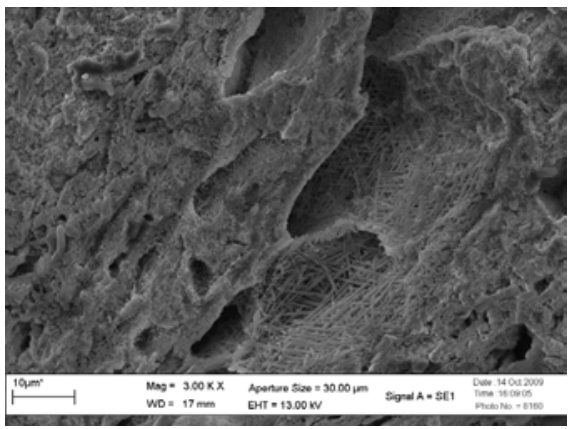

(b) $20 \mathrm{~min}$ in the power of the $90 \%$

Fig. 24. (a, b and c) - Microstructure of formulation 3 sintered in microwave power of $80 \%$ and $90 \%$ and times of 20 and 25 minutes

recrystallization were shown by Panneerselvam \& Rao (2003) in their studies. It was also possible to observe that the formation of secondary mullite occurs from large "gaps" or holes, probably due to the presence of the glassy phase.

By making a comparative analysis of the XRD diffractograms and microstructure by SEM, it was found that the formulations 1 and 2, sintered in the power of $80 \%$ and time $20 \mathrm{~min}$, showed peaks of mullite into sharper focus when compared to formulations 3, 4 and 5, noting that the amount of glassy phase present in these formulations, accelerated the reaction sintering with alumina to form mullite. This acceleration may have been caused due to the microwave effect, in which the microwave field results in drivers force that reduce the barriers of reaction very effectively (Panneerselvam \& Rao, 2003). On the other hand, the compositions with larger amounts of alumina needed to be submitted to the power and longer time to show the formation of secondary mullite. 


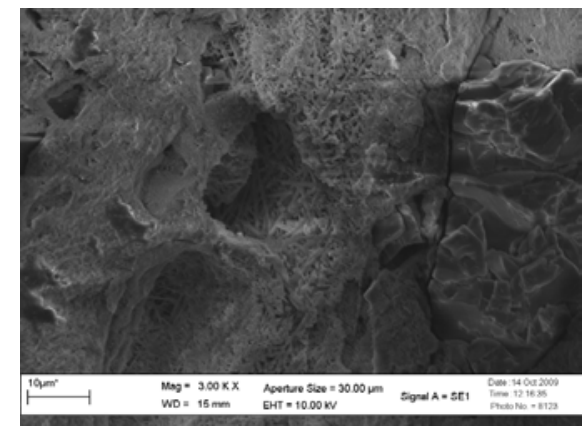

(a) $20 \mathrm{~min}$ in the power of the $80 \%$

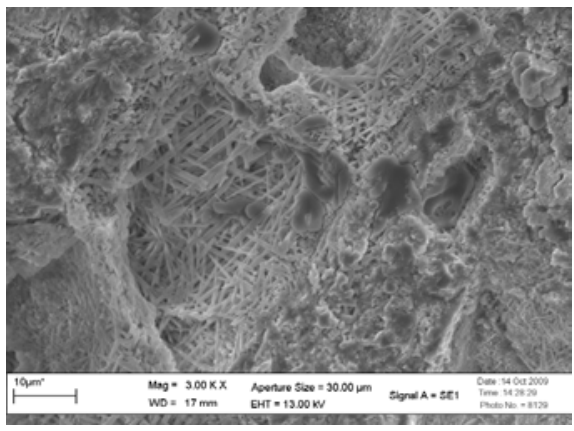

(b) $20 \mathrm{~min}$ in the power of the $90 \%$

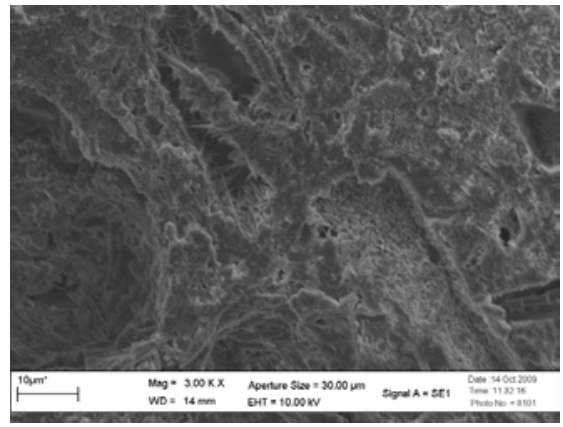

(c) $25 \mathrm{~min}$ in the power of the $90 \%$

Fig. 25. (a, b and c) - Microstructure of formulation 4 sintered in microwave power of $80 \%$ and $90 \%$ and times of 20 and 25 minutes 


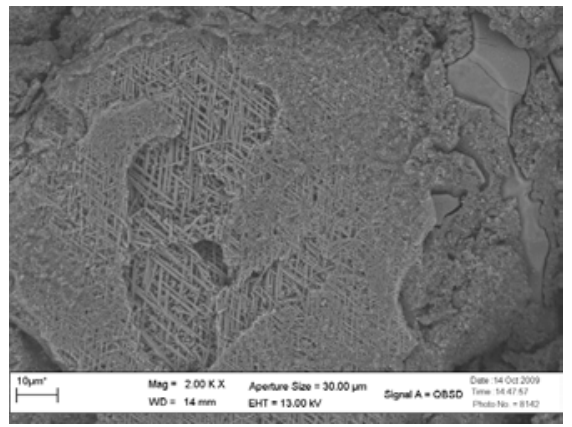

(a) $20 \mathrm{~min}$ in the power of the $80 \%$

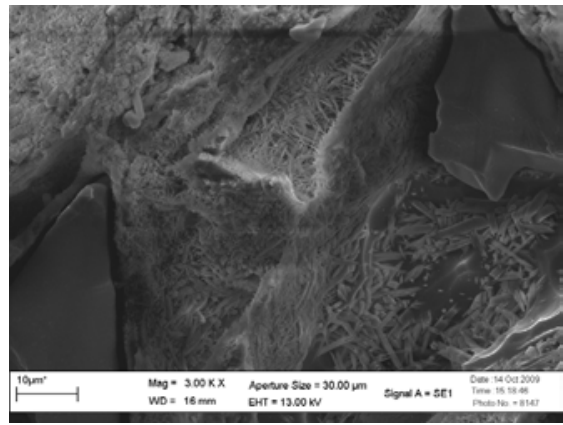

(b) $20 \mathrm{~min}$ in the power of the $90 \%$

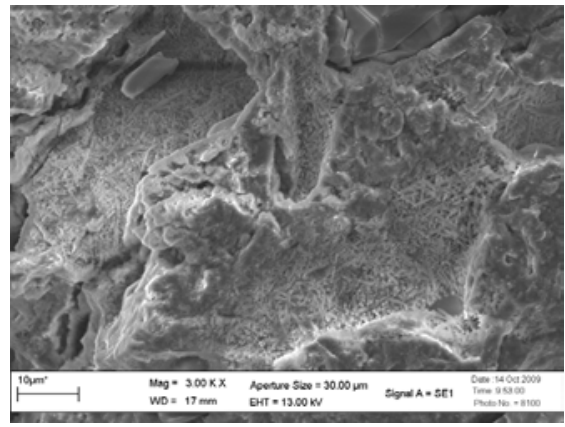

(c) $25 \mathrm{~min}$ in the power of the $90 \%$

Fig. 26. (a, b and c) - Microstructure of formulation 5 sintered in microwave power of $80 \%$ and $90 \%$ and times of 20 and 25 minutes 


\subsection{Comparison of results of the specimens sintered in microwave and conventional oven}

From the results obtained by the XRD diffractograms, it was observed that in just 20 min of sintering in a microwave oven, was the formation of secondary mullite. Time of $280 \mathrm{~min}$, for example, were required in conventional sintering, when the temperature was $1400^{\circ} \mathrm{C}$ for the formation of secondary mullite.

Ebadzadeh et al. (2009), stated in his studies that the process with microwave led to reduction $120{ }^{\circ} \mathrm{C}$ reduction in sintering temperature of specimens. Panneerselvam \& Rao (2003), stated that the maximum temperature of reaction, in obtaining mullite in a microwave oven was only $1312{ }^{\circ} \mathrm{C}$, which is much lower $\left(300-400{ }^{\circ} \mathrm{C}\right)$, the temperatures reported in conventional oven .

This fact focuses on the possible occurrence of a genuine effect of microwaves. According Panneerselvam \& Rao (2003), the microwave field is very intense in the interfaces, surfaces and cavities during irradiation. The microwave field results in drivers force that reduce the barriers of reaction very effectively. Thus, during the formation of secondary mullite, in particular, the effect of driving force can be responsible for the rapid diffusion of $\mathrm{Al}^{+3}$ ions in layers of $\mathrm{SiO}_{2}$.

By comparing the structure microstructure of the sintered samples in a microwave oven (Fig. 22 to 26) and in conventional oven (Fig. 12 to 16), can be seen that the microwave sintering provided the formation of secondary mullite needles more elongated and intertwined with each other. In all micrographs presented, it was not possible to measure the exact size of grains of single crystals due to aggregation and interconnectivity of the grains of primary and secondary mullite.

\section{Conclusion}

It was proved that after the study using kaolin waste in mixtures with alumina, it was concluded that these residues had characteristics suitable for the proposed use.

In this research the formation of secondary mullite is processed very quickly from the microwave, which might make this procedure satisfactory with regard to the economic aspect.

Factors such as power, time and temperature used was insufficient for complete reaction between alumina and silica to form mullite, however, the results indicate that mullite powders with better properties can be obtained from the microwave, the optimization of processing parameters.

Unable to determine the energy used during the reaction between alumina and silica to form mullite, both by microwave and by conventional oven, where such ovens did not have equipment for such analysis.

The results show the importance of studying the kaolin residue in obtaining mullite, conclude that, in addition to existing technical possibilities, one must highlight the socioeconomic viability of the process of obtaining mullite from kaolin residue, where large volumes of this are accumulated indiscriminately. 
The recycling of materials, represented here in this research by reusing the kaolin residue, is more than one action to try to save the planet, is one of the most important ways to ensure the development of peoples from the rational use of materials.

\section{Acknowledgements}

The authors thank CAPES and CNPq for financial support. Processes 479674/2007-8 and 307068/2007-2.

\section{References}

ABNT - ASSOCIAÇÃO BRASILEIRA DE NORMAS TÉCNICAS. NBR 10004: Resíduos Sólidos - Classificação, Rio de Janeiro, 2004.

Almeida, R.R. (2006). Reciclagem de resíduo de caulim e granito para produção de blocos e telhas. Dissertação de Mestrado. Campina Grande: CCT/UFCG, Coordenação de PósGraduação em Engenharia Civil, pp. 116..

Andrade, F.L.F., Varela, M.L., Dutra, R.P.S., Nascimento, R.M., Melo, D.M.A., Paskocimas, C.A. (2009). Avaliação da Potencialidade de Uso do Resíduo Proveniente da Indústria de Beneficiamento do Caulim na Produção de Piso Cerâmico. Cerâmica Industrial, 14, 1, pp.41-45.

Andreola, F., Barbieri, L., Corradi, A., Lancellotti, I., Manfredini, T. (2002). Utilisation of municipal incinerator grate slag for manufacturing porcelainized stoneware tiles manufacturing. Journal European Ceramic Society 22, pp.1457-.

Bartsch M., Saruhan B., Schmucker M., Schneider H. (1999). Novel low-temperature processing route of dense mullite ceramics by reaction sintering of amorphous $\mathrm{SiO}_{2}$-coated $\gamma$-alumina particle nanocomposites. Journal American Ceramic Society, 74, pp. $2448-2452$.

Brasileiro, M.I. et.al., (2006). Mullite Preparation from Kaolin Residue. Material Science Forum, v.530-531, pp. 625-630.

Brasileiro, M.I. et.al. (2008). Use of Kaolin Processing Waste for the Production of Mullite Bodies. Material Science Forum, v.591-593, pp. 799-804.

Brasileiro, M.I. (2010). Síntese de mulita por microondas utilizando composições contendo resíduo de caulim. Tese de Doutorado. Campina Grande, PB. Doutorado em engenharia de Processo CCT/UFCG.. pp. 112.

Castro, W.A.M.(2008). Incorporação de resíduo de caulim em argamassas para uso na construção civil. Dissertação de Mestrado. Campina grande: CCT/UFCG, Programa de Pós-Graduação em Ciência e Engenharia de Materiais. 98p.

Chen, C. Y., Lan, G.S., Tuan, W. H. (2000). Microstructural evolution of mullite during the sintering of kaolin powder compacts. Ceramic International, 26, p. 715-720, 2000.

Chen, C. Y.,Tuan W. H. (2001). The processing of kaolin powder compact. Ceramic International, 27,pp. 795-800.

Esharghawi, A., Penot, C., Nardou, F. (2009). Contribuition to porous mullite synthesis from clays by adding Al and Mg powders. Journal European Ceramic Society, 29, pp.31-38.

Flores, S.M.P., Neves, R.F. (1997). Alumina para utilização cerâmica, obtida a partir do rejeito de beneficiamento de caulim. $41^{\circ}$ Congresso Brasileiro de Cerâmica, São Paulo. Available from: 
http:/ / www.scielo.br/scielo.php?script=sci_pdf\&pid=S0366-

9131997000400005\&Ing=es\&nrm=iso\&tlng=pt.

IBRAM (2008) - Instituto Mineral Brasileiro - Panorama Mineral Brasileiro 2008. Disponível em: www.ibram.org.br. Available from: 20 de junho de 2011.

Iqbal, Y., Lee, W.E. (1999). Fired porcelain microstructures revisited. Journal American Ceramic Society, 82, 12, pp. 3584-3590.

Juettner, T., Moertel, H., Svinka, V., Svinka, R. (2007). Structure of kaolinite-alumina based foam ceramics for high temperature applications. Journal European Ceramic Society, 27, pp. 1435-1441.

Lima, F.T.; Gomes, J.; Neves, G.A.; Lira, H.L. (2001). Utilização do resíduo industrial resultantes do beneficiamento de caulim para fabricação de revestimentos cerâmicos. In: $45^{\circ}$ Congresso Brasileiro de Cerâmica, 2001, Florianópolis - SC. Anais. Associação Brasileira de Cerâmica, Florianópolis-SC, pp. 1501-1512.

Lima, M. S. (2005). Utilização do Resíduo de Caulim para uso em Blocos de Concreto sem Função Estrutural. Dissertação de Mestrado. (Mestrado em Engenharia Civil e Ambiental)-Universidade Federal de Campina Grande. Campina Grande, PB, 2005.

Mazdiyasni, K. S., Mah. (1983). Mechanical Properties of Mullite. Journal American Ceramic Society, 66, 10, pp. 699-704.

Menezes, R.R., De Almeida, R.R., Santana, L.N.L., Neves, G.A., Lira, H.L., Ferreira, H.C. (2007a). Análise da co-utilização do resíduo do beneficiamento do caulim e serragem de granito para produção de blocos e telhas cerâmicos. Cerâmica, v.53, p. 192-199.

Menezes, R.R.; Oliveira, M.F.; Santana, L.N. L.; Neves, G. A.; Ferreira, H.C. (2007b). Utilização do resíduo do beneficiamento do caulim para a produção de corpos mulíticos. Cerâmica, v.53, n³28, p.388-395.

Menezes, R.R., Souto, P.M., Kiminami, R.H.G.A. (2007c). Microwave hybrid fast sintering of porcelain bodies. Journal Materials Process Tecnic. 190, p. 223-229.

Menezes, R. R. ; Farias, F. F. ; Oliveira, M. F. ; Santana, L. N. L. ; Neves, G. A. ; Lira, H. L. ; Ferreira, H. C. (2009a). Kaolin processing waste applied in the manufacturing of ceramic tiles and mullite bodies. Waste Management $\mathcal{E}$ Research (ISWA), v. 27, pp. 78-86.

Menezes, R. R.; Brasileiro, M. I. ; Gonçalves, W. P. ; Santana, L. N. L.; Neves, G. A. ; Ferreira, H. S.; Ferreira, H. C. (2009b). Statistical design for recycling kaolin processing waste in the manufacturing of mullite-based ceramics. Materials Residue, v. 12, pp. 201209.

Meng, G., Huggins, R. A. (1993). New Chemical Method for Preparation of both Pure and Doped Mulite. Materials Residue Bulletin, v.18 (5),pp. 581-588.

Mileiko, S.T., Serebryakov, A.V., Kiiko, V.M., Kolchin, A.A., Kurlov, V.N., Novokhatskaya, N.I. (2009). Single crystalline mullite fibres obtained by the internal crystallisation method: Microstructure and creep resistance. Journal European Ceramic Society, 29, pp. 337-345.

Miranda, E. A. P., Neves, G. A., Lira, H. L. (2000). Reciclagem de Resíduos de Caulim e Granito para Uso Como Matéria-Prima Cerâmica. Anais do $45^{\circ}$ Congresso Brasileiro de Cerâmica, Florianópolis - SC- Brasil.

Monteiro, R.R., Sabioni, A.C.S., da Costa, A, G.M. (2004). Preparação de mulita a partir do mineral topázio. Cerâmica, v.50, pp.318-323. 
Neves, G.A., Almeida, R.R., Santana, L.N.L., Lira, H.L., Ferreira, H.C. (2006). Blocos cerâmicos utilizando resíduo de caulim. Anais do $50^{\circ}$ Congresso Brasileiro de Cerâmica - Blumenau - SC - Brasil.

Neves, Gelmires de Araújo et al., (2010). Resíduos industriais na construção de habitações de interesse social. $1^{\circ}$ Edition. Gráfica e Editora Agenda. Campina Grande - Paraíba Brazil.

Ozel, E., Turan, S., Çoruh, S., Ergun, O. N. (2006). Waste Management and Research , v.24, pp.125.

Panneerselvam, M. \& Rao, K.J. (2003). Novel Microwave Method for the Synthesis and Sintering of Mullite from Kaolinite. Chemical Materials, v.15, pp.2247-2252.

Pinatti, D. G., Conte, R. A., Borlini, M. C., Santos, B. C., Oliveira, I., Vieira, C. M. F., Monteiro, S. N. (2005). Incorporation of the ash from cellulignin into vitrified ceramic tiles. Journal European Ceramic Society, 26, p.305.

Rezende, M.L.S. (2007). Estudo de viabilidade técnica da utilização do resíduo de caulim em blocos de vedação. Dissertação de Mestrado. (Mestrado em Engenharia Agrícola) Coordenação de Pós-Graduação em Engenharia Agrícola,Universidade Federal de Campina Grande - Campina Grande.

Rocha, A. K. A. (2005). Incorporação de Resíduo de Caulim em Argamassa de Alvenaria. Dissertação de Mestrado. (Mestrado em Engenharia Civil e Ambiental)-Universidade Federal de Campina Grande. Campina Grande, PB. pp.95

Sakamoto, L. (2003). Os homens-tatu do sertão. Sertão potiguar, Rio Grande do Norte. Available from: http://www.reporterbrasil.com.br/caulim/iframe.php. 10/01/2010.

Santana, L. N. L. et.al. (2007). Influência das matérias-primas em corpos cerâmicos contendo resíduo de caulim. Anais do $51^{\circ}$ Congresso Brasileiro de Cerâmica de 3 a 6 de junho 2007 - Salvador - Bahia - Brazil - pp. 1-12.

Schneider, H., Okada, K., Pask, J. (1994). Mullite Synthesis. Mullite and Mullite Ceramics. Publisher: John Wiley \& Sons Ltda. Chichester: pp. 105-119.

Schneider, H., Komanerni, S. Mullite. Federal Republic of Germany, 2005.

Schneider, H., Schreuer, J., Hildmann, B. Structure and properties of mullite - A review. Journal European Ceramic Society, 28, p.329-344, 2008.

Scliar, C. (2003). Agenda 21 e o setor mineral. Brasília: Secretaria de Políticas para o Desenvolvimento Sustentável - MMA.

Silva, A.C., Vidal, M., Pereira, M.G. (2001). Impactos ambientais causados pela mineração e beneficiamento de caulim. Rem: Revista Escola de Minas, v.54, n.2, pp. 133-136.

Skoog, A. J., Moore, R. E. (1988). Refractory of the past for the future mullite and its use as a bonding phase. Journal American Ceramic Society Bulletin, 67, pp. 1180-1185.

Sola, E.R., Torres, F.J., Alarcón, J. (2006). Thermal evolution and structural study of 2:1 mullite from monophasic gels. Journal European Ceramic Society, 26, pp. 2279-2284.

SUDEMA (2004) - Superintendência de Administração do Meio Ambiente. Inventário de resíduos sólidos industriais do Estado da Paraíba. João Pessoa.

Vieira, S.C., Ramos, A.S., Vieira, M.T. (2007). Mullitization kinetics from silica and aluminarich wastes. Ceramic international, v. 33, pp. 59-66.

Viswabaskaran, V., Gnanam, F. D., Balasubramanian, M. (2003). Mullitisation behaviour of calcined clay-alumina mixtures. Ceramic International, v.29, pp.561 - 571.

Yu, J., Shi, J.L., Yuan, O.M., Yang, Z.F., Chen, Y.R. (1998). Mullitisation and Densification of alumina-rich aluminosilicate diphasic gel. Journal Materials Scince Letters, v.17, pp.1691-1693. 


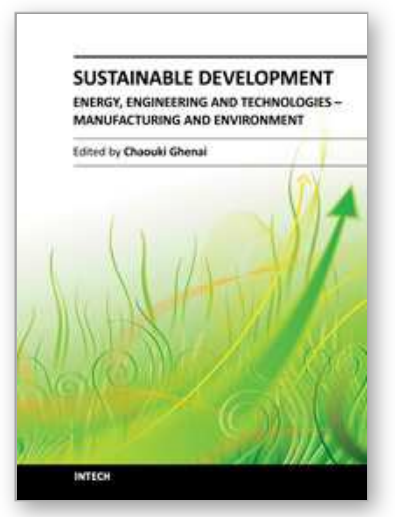

\author{
Sustainable Development - Energy, Engineering and Technologies \\ - Manufacturing and Environment \\ Edited by Prof. Chaouki Ghenai
}

ISBN 978-953-51-0165-9

Hard cover, 264 pages

Publisher InTech

Published online 29, February, 2012

Published in print edition February, 2012

The technological advancement of our civilization has created a consumer society expanding faster than the planet's resources allow, with our resource and energy needs rising exponentially in the past century. Securing the future of the human race will require an improved understanding of the environment as well as of technological solutions, mindsets and behaviors in line with modes of development that the ecosphere of our planet can support. Some experts see the only solution in a global deflation of the currently unsustainable exploitation of resources. However, sustainable development offers an approach that would be practical to fuse with the managerial strategies and assessment tools for policy and decision makers at the regional planning level. Environmentalists, architects, engineers, policy makers and economists will have to work together in order to ensure that planning and development can meet our society's present needs without compromising the security of future generations.

\title{
How to reference
}

In order to correctly reference this scholarly work, feel free to copy and paste the following:

M.I. Brasileiro, A.W.B. Rodrigues, R.R. Menezes, G.A. Neves and L.N.L. Santana (2012). The Kaolin Residue and Its Use for Production of Mullite Bodies, Sustainable Development - Energy, Engineering and Technologies - Manufacturing and Environment, Prof. Chaouki Ghenai (Ed.), ISBN: 978-953-51-0165-9, InTech, Available from: http://www.intechopen.com/books/sustainable-development-energy-engineering-andtechnologies-manufacturing-and-environment/the-kaolin-residue-and-its-use-for-production-of-mullite

\section{INTECH}

open science | open minds

\section{InTech Europe}

University Campus STeP Ri

Slavka Krautzeka 83/A

51000 Rijeka, Croatia

Phone: +385 (51) 770447

Fax: +385 (51) 686166

www.intechopen.com

\section{InTech China}

Unit 405, Office Block, Hotel Equatorial Shanghai

No.65, Yan An Road (West), Shanghai, 200040, China

中国上海市延安西路 65 号上海国际贵都大饭店办公楼 405 单元

Phone: +86-21-62489820

Fax: $+86-21-62489821$ 
(C) 2012 The Author(s). Licensee IntechOpen. This is an open access article distributed under the terms of the Creative Commons Attribution 3.0 License, which permits unrestricted use, distribution, and reproduction in any medium, provided the original work is properly cited. 